\title{
THE SPREAD OUT STRATEGY OF THE MAIN WEAPONS TOOL SYSTEM OF THE INDONESIAN AIR FORCE IN THE REGION OF THE REPUBLIC OF INDONESIA
}

\author{
Umar Sugeng Hariyono ${ }^{1}$ \\ Haedar Akib²
}

\section{Introduction}

In the lower operational level, especially in the era of the people's physical struggle for independence, the principle of "offense is the best defense" or "attack is the best defense", is still relevant. Nowadays, these statements are no longer applicable to the national strategic level. Actual experience shows that countries that run offensive strategies can be successful in the beginning of wars, but sometimes cannot hold it till the end. This was evident in World War I and World War II. This is the reason why according to Suryohadiprojo (2008), a country, in order to achieve its political objectives requires not only a "victory of war" but a "peaceful victory" after the end of wars. Thus, the expression that "an attack is the best defense", is no longer applicable as a National Strategy.

Nevertheless, in modern war theory, attack and defense are the two main forms for conducting a conflict. If diplomacy is not enough for a country to achieve its political objectives, then the use of force against other nations that are blocking these interests is seen as viable. On the other hand, nations that are attacked can fight back, on their own defense. To eliminate the source of the threat, defense must be able to eliminate or defeat attackers.

I Doctoral Candidate in Public Administration Sciences, Postgraduate Program of Makassar State University; Tentara Nasional Indonesia Angkatan Udara (TNI-AU).

2 PhD by the University of Indonesia (UI); Chair of the Department of Administrative Sciences, Faculty of Social Sciences, Universitas Negeri Makassar/ UNM, Indonesia. haedar652002@ yahoo.com.au 
Therefore, defense is a condition to be prepared to respond to others' attacks and eliminate the source of threat.

Potential threats due to the development of high technology methods and tools are expected to increase in the future. These potential threats can include terrorism, communal conflicts, transnational crime, crimes against state property, especially in the jurisdiction of Indonesia's marine and border areas, as well as the growing variety of conventional criminal acts (Setiyanti, Putranti, \& Rosyidin, 20I6; Witjaksono, 2016).

Threats and disruptions that affect the sovereignty of the state, territorial integrity and the safety of the nation, are closely linked to its strategic geographic position, natural resources, and human resources (HR). Other states' interests can threaten the survival of the country. For this reason, a sovereign country such as Indonesia requires a powerful or minimal defense weapon system tool (Alutsista) to defend the country and its people from various threats. One of the Alutsista that is owned by Indonesia is Air Alutsista, which is used to protect Indonesian air space. Air Alutsista is manned by the Indonesian National Army Air Force (TNI-AU) which currently has a considerable force posture in Asia and internationally.

Therefore, the goal of this article is to examine the strategy and placement of the Main Weapons Tool System (Alutsista) in the territory of the Unitary State of the Republic of Indonesia (NKRI). This study uses normative research methods conducted by reviewing references and is based on secondary data, added to concrete data and personal experiences.

\section{Discussion}

The dynamic development of today's global strategic environment, created a complex agenda of threats which impacts national defense. In addition, States are still competing for their interests and balancing forces. In the broad strategic governance, each State has its partnerships and strategic rivals, and is faced by diverse ideological pressures.

For instance, the alliance between the Islamic Republic of Iran and Communist China (PRC) and communist-socialist Russia is so strong, that were able to face the power of the United States and its allies. Similarly, the alliance between US-led liberal forces and Gulf Islamic countries, were able to balance the Islamic State of Iran in the Middle East region. Other examples are the spread of religious and sectarian radical groups (Azra, 20I6; Khamdan, 20I5) such as Al-Qaeda, the Islamic State of Iraq and Syria (ISIS) and its social impacts, such as the flow of refugees. This could foster the develop- 
ment of radical militant groups in other Muslim majority countries, including in Indonesia.

Therefore, to deal with these challenges, it is necessary to develop a strategy for the defense of the sovereignty and integrity of the Unitary State of the Republic of Indonesia (NKRI). First, we will examine a general concept of strategy and, second, the particular case of Indonesia.

The word "strategy" comes from the Greek word meaning "the art of the general," or the art of a commander who is usually used in war. The essence of a strategy is a means of achieving goals by using the available means of strength and infrastructure. Strategy is the science and art in the process of making decisions regarding goals, means, concepts, resources, strengths and potentials (TNI, 20I2: I8I; Makaarim A, 20I4).

Karl von Clausewitz (I780-I83I) argues that the notion of strategy is the knowledge of the use of combat to win the war (Umar, 200I). However, in this modern age, the use of the term strategy is no longer limited to the concept or art of a Commander in warfare, but has been used extensively almost in all fields of science. Whereas according to language, strategy means science and art use all the resources of the nations to exercise certain wisdom in war and peace (Depdiknas, 2008: 1529).

Understanding the concept of strategy, needs a comprehensive overview nowadays, that does not focus on a particular goal or on war. From a military power perspective study, strategy links military forces with the achievement of political goals. In other words, strategy is perceived as "... the use that is made of force and the threat of force at the ends of policy ..." (Gray, I999: I9). It departs from Clausewitz's approach which defines strategy as a form of engagement of war purposes. Thus, the explanation of strategy definitions always leads to a relationship between military power and political objectives. This strategic concept is then used as a guide for the application of a country's policy.

Based on the ideas of Clausewitz and Howard, Gray (I999) suggests several categories or dimensions that explain the concept of strategy, among others. The first dimension of strategy is located in the category of Preparation for War covering economics and logistics, organization, military administration, information and intelligence, doctrine and theory strategy, and technology. Second, the strategic dimension in the War Proper category is composed by military operations, leadership (in politics and military), geography, friction and opponents. These dimensions have contributed to the preparation and execution of strategy.

The first category shows that the preparation of a war strategy is a 
combination of several important dimensions, namely the economic resources of existing government supplies to drive the military machine directed by the strategy-making organization, recruited, armed, and trained. Also, it is linked to military management, associated with information, intelligence and the process of rationalization (Gray, I999: 3I). The first one is an important organizational dimension in providing institutional security in the future, in addition to its duties as a resistance and strength planner. However, it is argued that strategy is a process whereby the existing strategic idea needs to be coordinated, assessed and reviewed by an organization's bureaucrat. The next dimension is the dimension of military management, namely the preparation of military institutions, including the Air Force readiness for mobilization.

The second category is "war proper", which deals with the specifics of a military operation by displaying problems in command influenced by different geographical circumstances, shifting tasks, or being blocked by powerful enemies and subject to discipline (Gray, I999: 38). These categories illustrate the preparation and implementation of military operations of a strategy. This dimension shows the actual state of the relationship between strategy and tactics. Strategy is a brilliant idea which will only become a discourse if no one is running it. This dimension shows the reality of the application of a strategy itself. Also, the existence of command is a dimension that refers to the quality of the military and political leadership.

A strategy according to Luttwak, I987, in Gray (1999:42) is a plan that must be successful against non-natural enemies, through tactics, execution, strategic, and moral-political dialogue. Strategic goals are directed to secure profits agasint enemies, which should be contained and detained. According to Peter Wilson (I997 apud Gray, I999: 43), strategic ideas can be divided into three timelines: too early, late, or timely. Any strategic process of planning and implementimg, has a chronological dimension that limits and regulates it.

In the context of the Alutsista development, strategy can be interpreted as the art or the thinking of concepts in the efforts directed to develop and empower Alutsista TNI-AU based on the area and potential threats in order to achieve a strong and independent NKRI. Based on the TNI doctrine "Tri Dharma Eka Karma" abbreviated as "Tridek", the state defense strategy is to prevent, deter, and overcome threats and disturbance to the integrity of the nation and state in various forms and their manifestations by: I) Developing TNI capability as a main component to reinforce security and preparedeness 2) Building the people's capacity to productively strengthen defense and to maintain people's resistance. (TNI, 20I2).

In order to achieve Indonesia strategic goals, linked to TNI main 
tasks, Indonesian Air Force is a strong tactical mean. Main goals are going to be pursued according the formulation of the Strategy of Development and of the Development of TNI's Strength and Capacity, Strategy of Strengthening and Capacity of TNI, Strategy of Use of TNI's Strength and Capacity, and Third Coordination of TNI Strategy (Ways). All TNI strength and capabilities consisting of the strength and capabilities of the Army, the strength and capabilities of the Navy, and the strength and capabilities of the Supporting Component and the Reserve Component, including the budget capability of the Government of the Republic of Indonesia, will be empowered in the implementation of the TNI Strategy (Means) (TNI, 2OI2: 2I4). For the Indonesian nation, war is a last resort and is only done when all efforts are peacefully unsuccessful. To that end, the strategy of state defense needs to be drawn up by taking into account the three basic elements, namely: forming, responding, and preparing (Kementerian Pertahanan Republik Indonesia, 2015a, 2015b, $2015 \mathrm{C})$. The following describes the three elements of the defense strategy:

(I) Establish a strategy capable of creating and establishing national and international security environments that can ensure national interests to support regional stability, reduce and eliminate threats, prevent conflicts and aggression, as well as other acts of violence.

(2) Respond, which is a strategy capable of responding to the various spectrum of crisis, to eliminate threats and risks to the national interest.

(3) Prepare a strategy capable of establishing a defense for the Ministry of Defense of the Republic of Indonesia to face an uncertain future and to organize defense by maiking use of technological advances to protect the national interest.

In addition, the defense strategy of the state is formulated with three basic components of strategy in a proportional, balanced and coordinated way: first, the objective to be achieved is to safeguard and protect the sovereignty of the State, the territorial integrity of the Unitary Republic of Indonesia and to protect the safety of the entire nation (defined into five strategic objectives). Second, defense resources used to achieve goals such as the mobilization of military defense that is integrated and in synergy with the Nir-military defense. Third, how to use resources to achieve strategic objectives or goals, in order to plan, prepare and implement a strong and highly defensive state defense system in accordance with the Indonesian understanding of peace and war (Kementerian Pertahanan Republik Indonesia, 2015b).

Based on the theoretical perspective above, it can be argued that the strategy of Alutsista TNI-AU of the Republic of Indonesia is going to be established by examining the degree of its effectiveness throughout Indonesia. This effectiveness is linked to its ability to maintain the state's sovereignty 
and territorial integrity. In this sense, this paper will also present a potential model for Alutsita TNI AU deployment, by using the Soerjono \& Mamuji (2009) methodological research on quantitative and qualitative research.

\section{Power Alutsista TNI AU Currently}

Article ro of Law Number 34 the Year 2004 (Republik Indonesia, 2004) on the Indonesian National Army (TNI) stipulates that as an integral part of the TNI, the Air Force performs the task of TNI in the field of defense air defense; enforce the law and maintain security in the territorial air of national jurisdiction in accordance with the provisions of national law and ratified international law; carry out the tasks of the TNI in the development and development of air force forces; as well as implementing the empowerment of air defense areas. Recognizing the importance of the mandate of the law, the Air Force has been, is, and will continue to carry out its roles and functions actively in the face of all forms of threats, harassment and obstacles to maintain and secure the sovereignty and territorial integrity of NKRI.

Faced with various considerations especially the potential threat factor in the NKRI region and the limited ability of the defense equipment, the TNI AU develop Bare Base Concept. This concept deals with the current assessment of airbase readiness, including an evaluation of its facilities, maneuver abilities, and what can be made to increase the effectiveness of air operation. Currently, the Indonesian Air Force capabilities and strengthns is far from ideal conditions (Peraturan Kepala Staf Angkatan Udara, 20I5). The forces stand as:

(I) Air control- ability to control the security of the surface and under it without being threatened or attacked by the opponent. This task cannot be implemented optimally because of the limitations of armaments and weaponry.

(2) Air Attack- ability to use air power significantly based on the capability of destruction and the possibility to carry out air strikes against targets, both static and dynamic in the air, sea and land. This task also cannot be implemented in good conditions due to the limited capability of tankers, armaments and armaments.

(3) Air Support- ability to aid the implementation of air forces operations. This task, as well, is not able to be fully achieved due to limitations on defense materials.

(4) Information Exploitation- ability to make use of intelligence data to aid operations. Also limited.

Nowadays, TNI AU Alutsista is structured as: as Cuter-Fruit, includ- 
ing Cruise Missile (CM), Unmanned Aerial Vehicle (UAV), Tactical Airto-Surface Missile (TASM), Electronic Warfare (electronic warfare), Rockets Artillery Mortar (RAM), Fixed Wing Aircraft, Rotary Wing Aircraft (helicopter), Unmanned Combat Air Vehicles (UCAV), Intelligence, Surveillance, Target Acquisition, and Reconnaissance (ISTAR) and Tactical / Theater Ballistic Missiles TBM). However, special air defense systems that are manned by the Air Force consists of various types of aircraft, radar, missiles and air attack deterrent (PSU) (Kementerian Pertahanan Republik Indonesia, 20I5c; Kementerian Pertahanan Republik Indonesia, 2012).

Aircraft fighter carriers are very old, and one of them cannot be used again, but its replacement is still in the procurement process. Regarding quantity and quality, the material of TNI AU has experienced a great decrease in ability. While the support of TNI AU is located in fighter planes, transport planes, helicopters, trainers, radar and missiles. The condition of TNI AU outlines is as follows: I) Various types of aircraft, including Io 6 aircraft force fighter, 5I planes carrying aircraft, 39 helicopter power helicopters, 60 plane power trainers, and PTTA (Unmanned Aircraft) power of 4 aircraft. Then, Radar force of 20 units, QW-3 power missiles 273 sets, and PSU (Air Force Deterrent) power six.

TNI Commander General Gatot Nurmantio, revealed that there are potential threats to Indonesia that the country must be wary of: the Australian Border with Indonesia in the Masela Block; tension in the South China Sea; as well as the Five Defense Arrangement Defense Cooperation (PFDA) pioneered by the UK (Purbawanti, 20I6).

\section{The Placement Strategy of TNI AU Alutsista}

As argued, the power of Alutsista TNI AU is still insufficient to cover all its area of action. As stated by the Air Force Chief of Staff of TNI Hadi Tjahjanto, "Currently, the TNI AU Alutsista fulfills only $40 \%$ of its responsibility (...)" (Interview, Hadi Tjahyanto, 20I7). The area that is covered encompasses the islands of Java, Kalimantan and Sulawesi. Fighter aircraft for example, are held in eight air squadrons, namely (Command and Control Center of the Indonesian National Army Air Force (Puskodal) National Air Defense Command (Kohanudnas), August 23, 20I7; Observation and search results of various official sources, 20I7):

(I) One squadron Hawk Io9/209 (squadron I2), at Roesmin Nuryadin Lanes (RSN).

(2) One squadron FI6 (air squadron I6), at Lanud Roesmin Nuryadin 
(RSN). Lanud.

(3) One squadron Hawk Iog/209 (air squadron I2), in Pontianak

(4) One Sukhoi squadron (air squadron II) at Sultan Hasanuddin (HND) Makassar.

(5) One squadron T5oi (air squadron I4) in Lanud Iswahjudi Madiun.

(6) One squadron F-I6 (air squadron 3) at Lanud Iswahjudi Madiun.

(7) One squadron F5 (air squadron I5) at Lanud Iswahjudi Madiun.

(8) One Super Tucano squadron (air squadron 2I) at Lanud Abdrurrachman Saleh Malang.

However, of the eight air squadrons that manned the aircraft of the Air Force, two Hawk squadrons (Io9 and 209) and one F-5 squadron have retired, so the squadron that is still actively conducting the exercises and operations is only made of five squadrons. Based on the analysis of the potential threat and the extent of NKRI in Indonesia, the strategy of deploying TNI AU alutsista as follows:

Strategy to face potential threats on the border of Australia, by placing and holding a combat squadron at ElTari Airbus Kupang, East Nusa Tenggara (NTT). Gradually it can be done with the Mobile squadron strategy through the placement of several fighter aircraft along with the existing support personnel at ElTari Airbus Kupang, such as T-50 which will be upgraded to F-50 from Air Squadron I5 Lanud Iswahjudi Madiun. In addition to fighter aircraft, ElTari Kupang required PSU (Air Force Attack) such as Orlycon. Border Threats in Australia and the South China Sea Region (LCS). Darwin region, Australia is only approximately $475 \mathrm{~km}$ from the outer islands of Indonesia. The region contains Masela blocks that are part of the Indonesian territory and close to the concentration of foreign troops, such as United State (US) Marine, Marines of the United States numbering I,500-2,500 personnel. Also, the tension and warming of the LCS conditions that began the struggle for the Spratly archipelago rich in natural resources between ASEAN countries, the United States and China. China is currently treating air defense zones in the LCS Territory which will certainly cause conflicts surrounding countries with interest in LCS, so this is dangerous because the region is close to the Indonesian territory of Natuna Island.

Defense Arrangement (PFDA) Defense Cooperation (PFDA) which has been initiated by the countries joined in the British Commonwealth, namely Australia, New Zealand, Singapore, Malaysia and Britain itself. The combined strength of the PFDA is enormous, so it is important to be aware that these three countries are very close to Indonesia. Strategies that can be 
done by adding the air mobile squadron and its fighter plane that is always ready to be placed/held at Air Base (Lanud) Tarakan to anticipate the potential threat from countries incorporated PFDA.

In contrast to alutsista such as Radar, its deployment is almost in all parts of NKRI, although the number is still relatively minimal when compared with the area of NKRI. Radar has been deployed in twenty areas, namely: (I) Satrad 2II Tkt at Tanjung Kait; (2) Satrad 2I2 Rni in Ranai; (3) Satrad 2I3 Tpi in Tanjung Pinang; (4) Satrad 2I4 Pml in Pemalang; (5) Satrad 2I5 Cgt in Congot; (6) Satrad 2I6 Cbl in Cibalimbing; is in the area of Air Defense Sector Command I (Kohanudnas I) in Jakarta; (7) Satrad 22I Nli in Ngliyep; (8) Satrad 222 Plo di Ploso; (9) Satrad 223 Bpp Behind the Board; (Io) Satrad 224 Kwd in Kwandang; (II) Satrad 225 Trk in Tarakan; Satrad 226 Brn in Buraen; (I2) Satrad 23I Lse in Lhokseumawe; located in the area of Kosekhanudnas II in Makassar; (I3) Satrad 232 Dmi in Dumai; (I4) Satrad 233 Sat in Sabang; (I5) Satrad 234 As in Sibolga; (I6) Satrad 24I Brn in Buraen; located in the territory of Kosekhanudnas III in Medan; (I7) Satrad 242 in Biak; (I8) Satrad 243 in Timika; (I9) Satrad 244 in Merauke Papua; (20) Satrad 245 Saumlaki in Maluku, located in the area of Kosekhanud IV in Biak. TNI AU military radar coverage in the NKRI can be seen in the picture below.

\section{Fiqure 1. Placement of TNI-AU Radar}

\section{gelar RADAR haNUD 20 SatuaN BADAR}

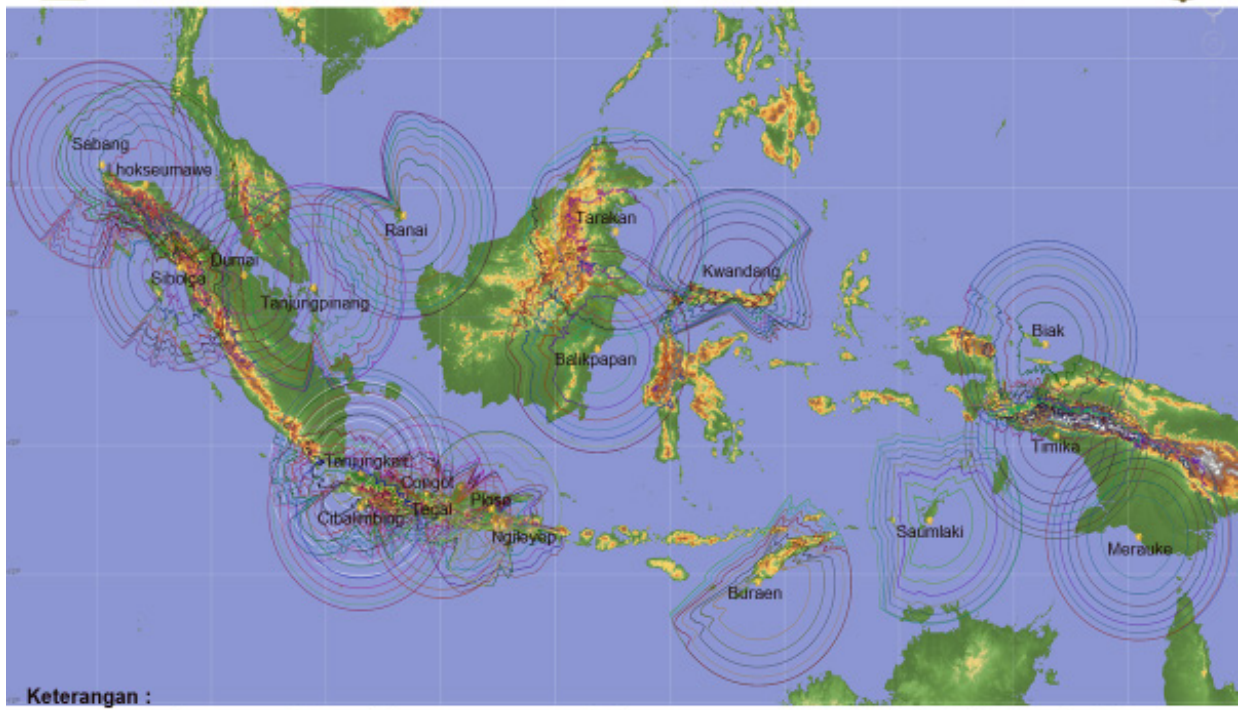

- 8 Tipe Radar Thomson : Sabang, Lhokseumawe, Dumai, Sibolga, Ranai, Tanjungkait (Banten), Cibalimbing (Sukabumi) dan Buraen (Kupang).

- 4 Tipe Radar Plessey Lama : Congot (yogyakarta), Tegal, Ploso (Jombang) dan Ngliyep (Malang).

- 3 Tipe Radar Plessey Baru : Balikpapan, Tarakan dan Kwandang (Gorontalo).

- 5 Tipe Radar Master T : Tanjungpinang, Biak, Saumlaki, Merauke, dan Timika. 
Source: Susanto \& Dicky (2015); Command and Control Center of the Indonesian National Army Air Force (Puskodal) National Air Defense Command (Kohanudnas), August 23, 2017.

Deployment of 20 Radar in NKRI region, according to the analysis of National Air Defense Command (Kohanudnas) there are 23 points that are still vulnerable to the threat and become a very easy area to be entered by the parties concerned to the Indonesian Nation. To protect the country from the threat of air, the Kohanudnas coordinated with the Radar unit under the control of the Ministry of Transportation and Angkasa Pura to place the Civil Radar at 23 points considered vulnerable. Coverage of Civilian radar that cannot be covered by military radar (TNI AU) in NKRI region can be seen in the picture below.

Figure 2. Coverage of Civilian Radar in Indonesian Territory

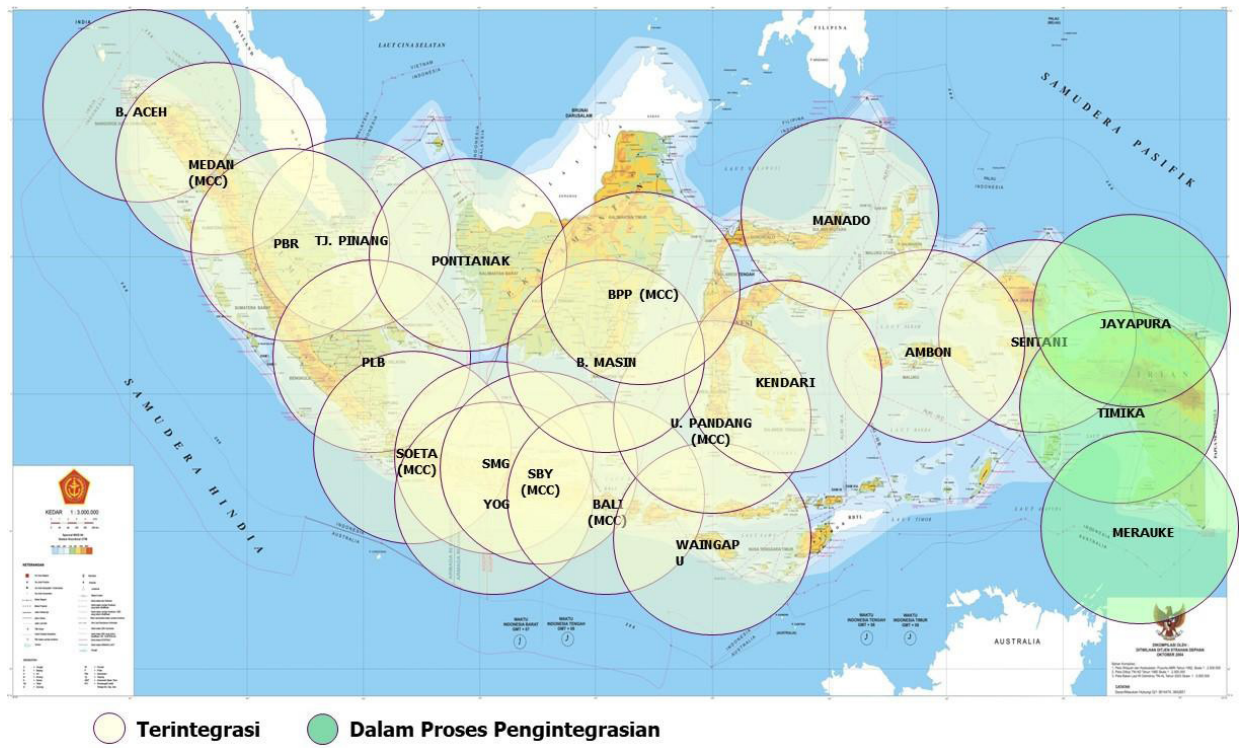

Source: Susanto \& Dicky (2015); Puskodal Kohanudnas, August 23, 2017.

However, the use of civilian Radar that has reached the 20 points cannot be used optimally. These civilian radars are only used to route planes that will use an airport ground to land. Coverage Condition of the Civilian and Military Radar currently can be read through the next image: 
Figure 3. Coverage of Civilian and Military Radar

COVERAGE RADAR MILITER DAN RADAR SIPIL

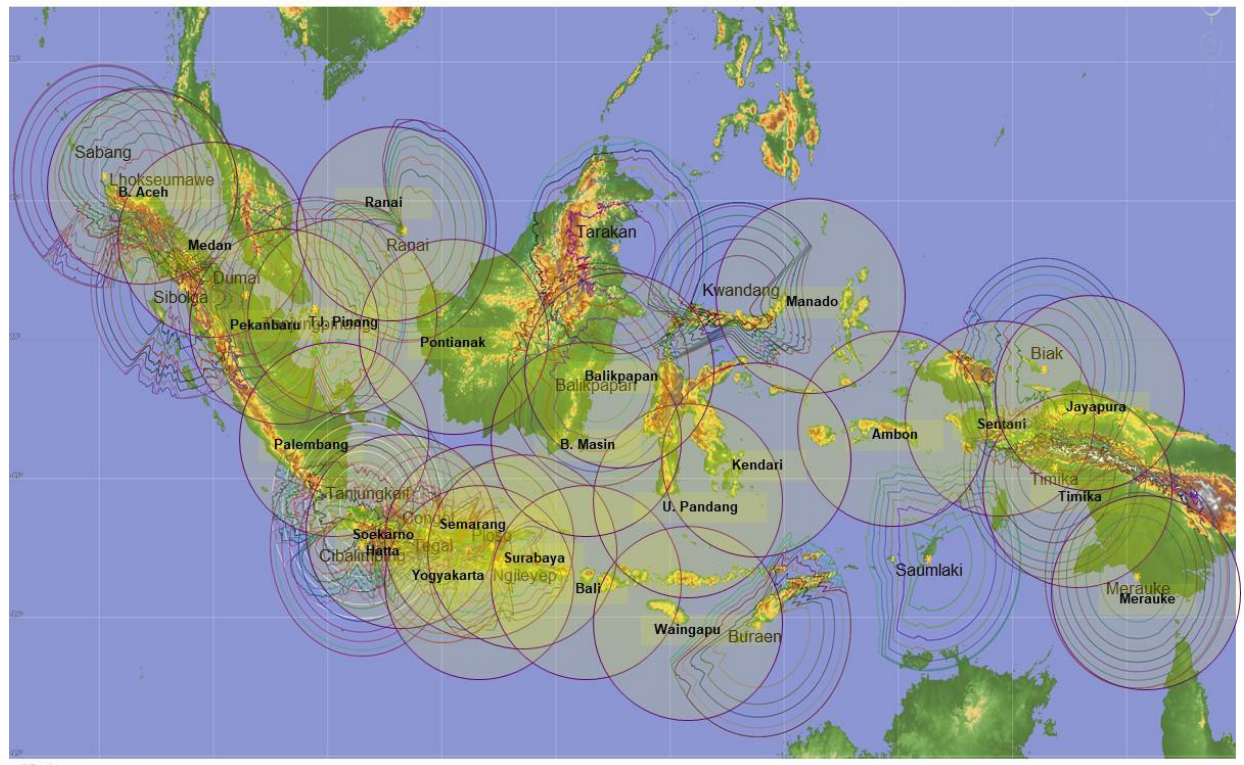

Keterangan:

- Coverage 20 Radar Militer dan 23 Radar Bandara Sipil

Source: Susanto \& Dicky (2015); Puskodal Kohanudnas, 23 Agustus 2017.

Due to the condition of Radar power owned by TNI AU under the control of Kohanudnas, for the sake of defense and security of the country, the development of military radar force (TNI AU) to cover 20 points of Civil Radar coverage becomes a demand that should be a priority for the country to monitor the whole territory NKRI. In the meantime, TNI AU weaponry in the form of Meriam hanud which serves as an air attack deterrent (PSU), both Triple Gun and Orlicon held in several areas, namely: (I) Detachment Hanud 473 / Kunta Wijayandanu-Pontianak; (2) Detachment of Hanud 472 / Kunta Wijayandanu-Makassar; (3) Detachment of Hanud 47I / Kunta Wijayandanu-Jakarta; and (4) Hanud 474 / Kunta Wijayandanu-Jogjakarta Detachment (Command and Control Center of the Indonesian National Army Air Force/Puskodal - National Air Defense Command/ Kohanudnas), August 23, 20I7).

In order to enable the forces to carry out its missions, the need is to:

Increase the Manuhua Lan from Type B to Type A by forming 2 (two) squadrons, combat squadrons and technical squadron. This is done to deal with potential threats in eastern Indonesia. 
Establish a fighter squadron at Eltari-Kupang Lanud to face potential threats from tensions on the Australia-Indonesia border.

Conducting 20 radars, to cover areas that are potentially vulnerable to enter or infiltrated parties interested in natural resources in Indonesia. There are 23 (twenty three) vulnerable points during this time assisted by the civilian radar of the Ministry of Transportation.

\section{Conclusions and recommendations}

So far, the Alutsista TNI AU covers only $40 \%$ of the need territory in Indonesia, such as the regions of Java, Sumatra, Kalimantan and Sulawesi. Othe regions that need attention in the territory are Papua, Maluku, West Nusa Tenggara, East Nusa Tenggara and Bali. Also, 23 radars are being added to be deployed in the blank spot areas that have been covered by civilian radar. Based on that reality, it is suggested to the government and the House of Representatives (DPR) that the budget for TNI AU needs to be expanded, in order to fulfill the minimum basic force requirements for protecting Indonesia.

\section{REFERENCES}

Azra, A. (20I6). Transformasi politik Islam: radikalisme, khilafatisme, dan demokrasi. Kencana.

Depdiknas, P. B. (2008). Pusat Bahasa Departemen Pendidikan Nasional. Kamus Bahasa Indonesia. Jakarta.

Gray, C. S. (1999). “The Dimension of Strategy”, in Modern strategy (Vol. 42). Oxford University Press Oxford.

Kementerian Pertahanan Republik Indonesia. (20I2). Peraturan Menteri Pertahanan Republik Indonesia Nomor I9 Tahun 2012 Tentang Kebijakan Penyelarasan Minimum Essential Force Komponen Utama. Jakarta: Kementerian Pertahanan (Kemhan) Republik Indonesia.

Kementerian Pertahanan Republik Indonesia. (2015a). Buku Putih Pertahanan Indonesia. Jakarta: Kementerian Pertahanan (Kemhan) Republik Indonesia.

Kementerian Pertahanan Republik Indonesia. (2015b). Doktrin Pertahanan Negara. Jakarta: Kementerian Pertahanan (Kemhan) Republik Indonesia.

Kementerian Pertahanan Republik Indonesia. (20I5c). Postur Pertahanan Ne- 
gara. Jakarta: Kementerian Pertahanan Republik Indonesia.

Khamdan, M. (20I5). Rethinking Deradikalisasi: Konstruksi Bina Damai Penanganan Terorisme. ADDIN, 9(I).

Lykke Jr, A. F. (I997). Defining military strategy. Military Review. US Army CGSC.

Makaarim A, M. (20I4). Almanak Hak Asasi Manusia di Sektor Keamanan Indonesia. (M. M. A., Ed.).

Peraturan Kepala Staf Angkatan Udara. (2015). Nomor 47 Tahun 2015 Tentang Kelanjutan Pembangunan Kekuatan Pokok Minimum (Minimum Essential Force) TNI Angkatan Udara Tahun 20I5-2024. Jakarta, Indonesia: Markas Besar Tentara Nasional Indonesia Angkatan Udara (TNI-AU).

Purbawanti, N. N. S. (20I6). Pengaruh Konflik Laut China Selatan Terhadap Stabilitas Keamanan Di Indonesia. PERPUSTAKAAN.

Republik Indonesia. (2004). Undang-Undang Nomor 34 Tahun 2004 tentang Tentara Nasional Indonesia. Jakarta, Indonesia.

Setiyanti, D., Putranti, I. R., \& Rosyidin, M. (20I6). Potensi Ancaman ASEAN Open Sky Policy 20I5 Terhadap Keamanan Nasional Indonesia. Journal of International Relations, 2(4), IO-I8.

Soerjono, S., \& Mamuji, S. (2009). Penelitian Hukum Normatif Suatu Tinjauan Singkat. Jakarta: PT. Raja Grafindo.

Suryohadiprojo, S. (2008). Pengantar ilmu perang. Pustaka Intermasa.

Susanto, D. R. M., \& Dicky, R. (2015). Komando dan Pengendalian Keamanan dan Keselamatan Laut: Berbasis Peringatan Dini. Jakarta, Indonesia: PT Gramedia Pustaka Utama.

TNI, D. (2012). Tri Dharma Eka Karma (Tridek), Jakarta.

Umar, H. (200I). Strategic management in action. Gramedia Pustaka Utama.

Witjaksono, M. T. N. I. (20I6). Strategi dalam Upaya Mempertahankan Bangsa dan NKRI. In Seminar Nasional (p. I28). Bandung: Fakultas Psikologi Universitas Padjadjaran. 


\section{ABSTRACT}

The goal of this article is to examine the strategy and placement of the Main Weapons Tool System (Alutsista) in the territory of the Unitary State of the Republic of Indonesia (NKRI). One of the Alutsista owned by Indonesia is Air Alutsista which is used to protect Indonesian air space. The air alutsista manned by the Indonesian National Army (TNI) Air Force (AU) currently has a considerable power projection in Asia and the world. This study uses normative research methods conducted by reviewing references and is based on secondary data, added to concrete data and personal experiences. The research shows that the placement of Alutsita is equally distributed on the NKRI archipelago, and examines its strength power in specific regions.

\section{KEYWORDS}

Weapons System; Air Power; Indonesia.

Received on June 6, 2018

Approved on April 10, 2019 